\title{
Antioxidant properties and fruit quality of selected papaya breeding lines
}

\author{
Kritsanee Iamjud $^{\mathrm{a}}$, Supornpan Srimat ${ }^{\mathrm{a}}$, Peerapong Sangwanangkul ${ }^{\mathrm{b}}$, Sirikul Wasee $^{\mathrm{c}}$, \\ Kriengsak Thaipong ${ }^{\mathrm{a}, \mathrm{d}, *}$ \\ a Department of Horticulture, Faculty of Agriculture at Kamphaeng Saen, Kasetsart University, \\ Kamphaeng Saen Campus, Nakhon Pathom 73140 Thailand \\ b Postharvest Technology Centre, Department of Horticulture, Faculty of Agriculture at Kamphaeng Saen, \\ Kasetsart University, Kampaeng Saen Campus, Nakhon Pathom 73140 Thailand \\ c Tropical Vegetable Research Centre, Department of Horticulture, \\ Faculty of Agriculture at Kamphaeng Saen, Kasetsart University, Kamphaeng Saen Campus, \\ Nakhon Pathom 73140 Thailand \\ d Tropical Fruit Research and Development Centre, Department of Horticulture, \\ Faculty of Agriculture at Kamphaeng Saen, Kasetsart University, Kamphaeng Saen Campus, \\ Nakhon Pathom 73140 Thailand
}

*Corresponding author, e-mail: kriengsak.t@ku.ac.th

Received 26 Jul 2015

Accepted 24 May 2016

ABSTRACT: Nine selected $S_{3}$ papaya breeding lines were evaluated for their antioxidant properties and fruit quality. The 14 antioxidant properties and fruit quality traits measured in this study showed significant genotypic differences. KK80 showed the highest ascorbic acid content $(114 \pm 20 \mathrm{mg} / 100 \mathrm{ml})$, antioxidant activity $(8.0 \pm 1.3 \mu$ mol ascorbic acid equivalents/g fresh weight $[\mathrm{FW}]$ ), and total phenolic compounds (72.2 $\pm 5.8 \mathrm{mg}$ gallic acid equivalents/100 $\mathrm{g}$ FW). KD7 contained the highest amounts of total flavonoid (21.0 $\pm 5.8 \mathrm{mg}$ catechin equivalents/100 $\mathrm{g}$ FW), lycopene $(11.0 \pm 1.7 \mathrm{mg} / 100 \mathrm{~g} \mathrm{FW})$, and $\beta$-carotene $(10.0 \pm 1.7 \mathrm{mg} / 100 \mathrm{~g} \mathrm{FW})$. The significant variation in antioxidant properties and fruit quality clearly shows the potential value of selected papaya breeding lines as new cultivars and parents in a breeding programme. Lycopene had a positive correlation with $\beta$-carotene $(r=0.62)$. Fruit size showed a negative correlation with total phenolic compounds $(r=-0.64)$, antioxidant activity $(r=-0.45)$, and ascorbic acid $(r=-0.44)$. Flesh colour as hue angle was negatively correlated to lycopene $(r=-0.67)$, suggesting that lycopene may be estimated indirectly by using the hue angle.

KEYWORDS: papaya breeding, antioxidant compounds, carotenoids

\section{INTRODUCTION}

Currently, there is an increasing interest in the selection of crops with higher antioxidant contents. Phenolic and flavonoid compounds and lycopene are effective antioxidants, while $\beta$-carotene is a precursor of vitamin A. They have become widely studied due to their free-radical scavenging properties which confer them potentially beneficial properties to human health ${ }^{1}$. Several epidemiological studies suggest that diets high in carotenoid pigments are associated with a reduced risk of cardiovascular diseases, prostate cancer, and lung cancer. Papaya (Carica papaya) fruit is a good source of carotenoids and an excellent source of vitamins that are powerful antioxidants ${ }^{2}$.

Several studies have reported the relationship between fruit quality and the antioxidant content of different fruits, for instance, the correlation of the fruit size and antioxidant contents of guava ${ }^{3}$, internal fruit colour and carotenoid contents of mango ${ }^{4}$, and flesh colour and lycopene content of tomato ${ }^{5}$. The knowledge of the relationship between fruit quality traits and antioxidants is a useful tool to estimate whether selection for one trait will have an effect on another trait and so it can be used for indirect selection.

In Thailand, papaya is an important commercial crop. However, the existing commercial papaya varieties of Thailand, such as 'Khaek Dam' and 'Plug Mai Lai' are not homozygous varieties and have some undesirable characters for both fresh consumption and processing. The papaya breeding program was therefore established in 2009 by the 
Department of Horticulture, Faculty of Agriculture at Kamphaeng Saen, Kasetsart University, Kamphaeng Saen campus, Nakhon Pathom, Thailand to produce homozygous varieties with superior fruit qualities and high in antioxidants. Some $\mathrm{S}_{3}$ generation breeding lines were selected based on their high productivity. The purpose of this study was to evaluate antioxidant compounds, fruit quality, and determine a correlation between of selected papaya breeding lines to find cultivars high in antioxidants with good fruit quality for use as new commercial cultivars or parents for a future papaya breeding program.

\section{MATERIALS AND METHODS}

\section{Plant materials}

Ten fruits per genotype were harvested in June 2013 from the hermaphrodite plant of nine selected $\mathrm{S}_{3}$ papaya breeding lines (KD2, KD5, KD7, KD22, PML, RL, KK80, SKK, and MK) at the Tropical Vegetable Research Centre, Department of Horticulture, Faculty of Agriculture at Kamphaeng Saen, Kasetsart University, Kamphaeng Sean Campus, Nakhon Pathom, Thailand. Fruits were harvested at 25\% skin yellow, a commercial maturity stage harvesting index that can function as quality standards for ripe consumption papaya ${ }^{6}$. The samples were then stored at room temperature $\left(27 \pm 2{ }^{\circ} \mathrm{C}\right)$ until fully ripened before evaluation.

\section{Evaluation of fruit quality traits}

Fruit weight $(\mathrm{kg})$ was measured using a digital scale (SK-5001, A\&D, Japan). Then the papaya fruit was cut in half transversally at the equatorial region. Flesh thickness $(\mathrm{cm})$, flesh colour, flesh firmness $\left(\mathrm{kg} / \mathrm{cm}^{2}\right)$, and total soluble solids (TSS, \%) were measured at the midpoint of the fruit. Flesh colour was determined using a colour reader (CR-10 Minolta Co., Ltd, Japan). $L, a$, and $b$ values were recorded. The $L$ value represented the luminosity of the fruit, where $0=$ black and $100=$ white. The $a$ value ranged on a scale from the negative (green) to the positive (red). The $b$ value ranged on a scale from the negative (blue) to the positive (yellow). Hue angle $(h)$, an indicator of colour changes from green to yellow to red, was calculated from $a$ and $b$ values as $h=\tan ^{-1}(b / a)^{7}$. A colour wheel subtends $360^{\circ}$, with red-purple traditionally placed at an angle of $0^{\circ}$, yellow, bluish-green, and blue follow anticlockwise at $90^{\circ}, 180^{\circ}$, and $270^{\circ}$, respectively. Flesh firmness was determined by means of a fruit hardness tester (N.O.W., Japan) using a $1.2 \mathrm{~cm}$ diameter probe. TSS was measured by the use of a pocket refractometer (PAL-1, Atago, Japan).

\section{Ascorbic acid determination}

Ascorbic acid content $(\mathrm{mg} / 100 \mathrm{ml})$ in juice directly extracted from flesh at the fruit midpoint was measured using the 2,6-dichloroindophenol titrimetric $\operatorname{method}^{8}$.

\section{Extraction for phenolic and antioxidant activity analysis}

For antioxidant activity, total flavonoid, and phenolic extraction, $3 \mathrm{~g}$ of each papaya flesh central part were homogenized in $20 \mathrm{ml}$ of methanol using an Ultra-Turrax homogenizer (T25, Ika Works Inc., USA). The homogenates were then centrifuged at $30900 \mathrm{~g}$ for $20 \mathrm{~min}$. The supernatant was recovered and stored at $-20^{\circ} \mathrm{C}$ until analysis.

\section{Total phenolic and flavonoid determinations}

Total phenolic content was determined by the FolinCiocalteu method ${ }^{9}$. By the original, this method was developed in Prunus domestica whose flesh has much higher phenolic content than papaya flesh. Consequently, some adaptations were required as follows. The $150 \mu \mathrm{l}$ of flesh extract was mixed with $2400 \mu \mathrm{l}$ of distilled water $\left(\mathrm{dH}_{2} \mathrm{O}\right)$ and $150 \mu \mathrm{l}$ of $0.25 \mathrm{~N}$ Folin-Ciocalteu reagents and mixed well using a Vortex (Vortex-2 genie, USA). The mixtures were allowed to react for $3 \mathrm{~min}$ and then $300 \mu \mathrm{l}$ of $1 \mathrm{~N} \mathrm{Na}_{2} \mathrm{CO}_{3}$ solution was added and mixed well. The solution was incubated at room temperature $\left(25^{\circ} \mathrm{C}\right)$ in a dark condition for $2 \mathrm{~h}$. The absorbance was measured at $725 \mathrm{~nm}$ using a spectrophotometer (T80 UV-Vis spectrometer, PG Instruments, USA). Total phenolic content was expressed as mg gallic acid equivalents (GAE)/100 $\mathrm{g}$ fresh weight (FW).

Total flavonoid content was assessed by colorimetric assay ${ }^{10}$. One $\mathrm{ml}$ of flesh extract was mixed with $4 \mathrm{ml}$ of $\mathrm{dH}_{2} \mathrm{O}$ and then stood for $5 \mathrm{~min}$. Then $0.3 \mathrm{ml}$ of $5 \% \mathrm{NaNO}_{2}$ and $0.3 \mathrm{ml}$ of $10 \% \mathrm{AlCl}_{3}$ were added and mixed well with the Vortex and stood for another $6 \mathrm{~min}$. Two $\mathrm{ml}$ of $1 \mathrm{M} \mathrm{NaOH}$ were added and diluted to $10 \mathrm{ml}$ with $\mathrm{dH}_{2} \mathrm{O}$. The mixture was measured immediately at $725 \mathrm{~nm}$ using the spectrophotometer. Total flavonoid content was expressed as mg catechin equivalents (CE)/100 g FW.

\section{Antioxidant activity determination}

Antioxidant activity was determined by the ferric reducing/antioxidant power (FRAP) method ${ }^{11}$, the 
original was measured in plasma. Hence, some adjustments were necessary, as follows. The FRAP solution was prepared daily by mixing $25 \mathrm{ml}$ of $300 \mathrm{mM}$ acetate buffer (pH 3.6), $2.5 \mathrm{ml}$ TPTZ solution $(10 \mathrm{mM}$ in $40 \mathrm{mM} \mathrm{HCl})$, and $2.5 \mathrm{ml}$ of $20 \mathrm{mM}$ $\mathrm{FeCl}_{3} \cdot 6 \mathrm{H}_{2} \mathrm{O}$ solution. The solution was warmed at $37^{\circ} \mathrm{C}$ for $30 \mathrm{~min}$ in an incubator (Polar 1000C, Contherm, New Zealand) before use. Seventy five $\mu 1$ of flesh extract was mixed with $75 \mu 1$ methanol. The fusions were then mixed with $2850 \mu$ l of warmed FRAP solution and mixed well using the Vortex. The mixtures were allowed to react at $37^{\circ} \mathrm{C}$ for $60 \mathrm{~min}$ in the incubator. Absorbance was then taken at $593 \mathrm{~nm}$ using the spectrophotometer. Antioxidant activity was expressed as $\mu \mathrm{mol}$ ascorbic acid equivalents (AAE) per g FW.

\section{Carotenoids determinations}

For lycopene and $\beta$-carotene, $0.2 \mathrm{~g}$ of each papaya pulp (central part) were homogenized in $20 \mathrm{ml}$ of solvent hexane:ethanol:acetone at 2:1:1 $1^{12}$. Three $\mathrm{ml}$ of water were added and stood for $15 \mathrm{~min}$ to cause a phase separation. The upper hexane phase content was measured to determine the absorbance at 444 and $503 \mathrm{~nm}$ using a spectrophotometer (Genesys 10S UV-Vis, Thermo Scientific, USA). The contents (mg/100 g FW) of both lycopene and $\beta$-carotene were calculated according to

$$
\begin{aligned}
C_{\mathrm{ly}} & =\left(6.95 A_{503}-1.59 A_{444}\right)(0.55)(537)(\mathrm{V} / W) / 10, \\
C_{\beta c} & =\left(9.38 A_{444}-6.70 A_{503}\right)(0.55)(537)(\mathrm{V} / W) / 10,
\end{aligned}
$$

respectively, where 0.55 is the ratio of the final hexane layer volume to the volume of mixed solvents added, 537 is the molecular weights of lycopene and $\beta$-carotene $(\mathrm{g} / \mathrm{mol}), W(\mathrm{mg})$ is the weight of papaya tissue analysed, $V(\mathrm{ml})$ is the volume of mixed solvents added, and 10 is for the adjustment to $\mathrm{mg} / 100 \mathrm{~g}$ units.

\section{Statistical analysis}

All data were expressed in mean \pm standard deviation. ANOVA was performed. The means were separated using Bonferroni test at 0.05 level. Linear relationships among data were analysed using Pearson's correlation coefficient $(r)$.

\section{RESULTS AND DISCUSSION}

\section{Fruit quality traits}

Fruit quality traits of nine selected $S_{3}$ papaya breeding lines based on ripe fruit displayed significant differences for all traits (Table 1).
Table 1 ANOVA showing genotype mean square and probabilities $(p)$ of test statistics for the fruit quality traits in 9 selected $S_{3}$ papaya breeding lines.

\begin{tabular}{lcc}
\hline Trait & Genotype mean square & $p$ \\
\hline Fruit weight & 1.00 & $<0.01$ \\
Flesh thickness & 0.82 & $<0.01$ \\
$L$ & 36.04 & $<0.01$ \\
$a$ & 147.13 & $<0.01$ \\
$b$ & 70.30 & $<0.01$ \\
Hue angle & 145.97 & $<0.01$ \\
Firmness & 2.63 & $<0.01$ \\
Total soluble solids & 13.35 & $<0.01$ \\
\hline
\end{tabular}

The averaged fruit weight was $1.0 \pm 0.4 \mathrm{~kg}$, ranging from $0.4 \pm 0.1$ in KK80 to $1.4 \pm 0.5 \mathrm{~kg}$ in RL. The averaged flesh thickness was $2.4 \pm 0.3 \mathrm{~cm}$, ranging from $2.0 \pm 0.2$ in KK80 to $2.9 \pm 0.3$ in SKK and MK (Table 2). Large fruit size $(\geqslant 1.0 \mathrm{~kg})$ is an important characteristic for the industrial use of papaya by the food industry. For fresh consumption, especially in Thailand, small fruit with a size of about $0.5 \mathrm{~kg}$ is tending to be more favoured by consumers because the current and future family size is smaller than in the past. For this reason, most selected $\mathrm{S}_{3}$ papaya breeding lines, especially $\mathrm{RL}$ and $\mathrm{KD} 2$, are suitable for the food industry, while PML and KK80 are suitable for fresh consumption.

Flesh colour varied from orange to reddishorange depending on the cultivars. The increased intensity of the reddish-orange colour was accompanied by a decrease in hue angle value. The averaged hue angle value was $40.5^{\circ} \pm 4.6^{\circ}$, ranging from $35.3^{\circ} \pm 3.0^{\circ}$ in $\mathrm{KD} 2$ (red flesh) to $46.3^{\circ} \pm 3.2^{\circ}$ in SKK (orange flesh) (Table 2). The hue angle value in selected papaya breeding lines was quite low as compared to previous reports in commercial papaya cultivars. Chantorn ${ }^{13}$ reported the hue angle of 'Khaek Dam' and 'Pluk Mailai' averaged $52.1^{\circ}$ and $43.4^{\circ}$, respectively; and $59.4^{\circ}$ in the 'Sunrise' culti$\operatorname{var}^{14}$.

Fruit firmness and total soluble solids are the most important factors for the determination of papaya quality for consumer preference. The MK cultivar flesh was very firm and had the highest firmness value $\left(2.6 \mathrm{~kg} / \mathrm{cm}^{2}\right)$. In contrast, SKK had the lowest firmness value $\left(0.9 \mathrm{~kg} / \mathrm{cm}^{2}\right)$. The averaged TSS value was $12 \%$. The highest TSS value belonged to PML (15\%) and the lowest content of TSS was recorded in KD2 and SKK (11\%) (Table 2). The standard of TSS for papaya was accepted to be more than $10 \%$ (Thailand) ${ }^{15}$ and $12 \%$ (Hawaii) ${ }^{16}$. 
Table 2 Fruit quality traits of nine selected $S_{3}$ papaya breeding lines.

\begin{tabular}{|c|c|c|c|c|c|c|c|c|}
\hline \multirow[t]{2}{*}{ Genotype } & \multirow{2}{*}{$\begin{array}{c}\text { Fruit weight } \\
\qquad(\mathrm{kg})\end{array}$} & \multirow{2}{*}{$\begin{array}{l}\text { Flesh thick- } \\
\text { ness (cm) }\end{array}$} & \multicolumn{4}{|c|}{ Flesh colour } & \multirow{2}{*}{$\begin{array}{l}\text { Firmness } \\
\left(\mathrm{kg} / \mathrm{cm}^{2}\right)\end{array}$} & \multirow{2}{*}{$\begin{array}{l}\text { TSS } \\
(\%)\end{array}$} \\
\hline & & & $L$ & $a$ & $b$ & Hue angle $\left({ }^{\circ}\right)$ & & \\
\hline KD2 & $1.3 \pm 0.4$ & $2.6 \pm 0.2$ & $41.4 \pm 2.5$ & $43.4 \pm 1.4$ & $30.9 \pm 2.9$ & $35.3 \pm 3.0$ & $1.1 \pm 0.5$ & $11.4 \pm 0.6$ \\
\hline KD5 & $1.2 \pm 0.4$ & $2.4 \pm 0.3$ & $43.1 \pm 3.2$ & $43.1 \pm 2.0$ & $32.7 \pm 2.2$ & $37.2 \pm 2.7$ & $1.4 \pm 0.6$ & $11.6 \pm 1.5$ \\
\hline KD7 & $1.0 \pm 0.3$ & $2.3 \pm 0.1$ & $43.8 \pm 2.5$ & $45.1 \pm 3.5$ & $34.5 \pm 3.1$ & $37.4 \pm 3.1$ & $1.6 \pm 0.4$ & $12.0 \pm 1.1$ \\
\hline KD22 & $0.9 \pm 0.1$ & $2.1 \pm 0.1$ & $47.0 \pm 1.9$ & $46.0 \pm 3.6$ & $37.9 \pm 2.6$ & $39.5 \pm 2.9$ & $1.0 \pm 0.2$ & $11.9 \pm 0.9$ \\
\hline PML & $0.6 \pm 0.2$ & $2.4 \pm 0.2$ & $48.2 \pm 1.2$ & $37.3 \pm 3.7$ & $38.5 \pm 1.4$ & $46.0 \pm 3.4$ & $1.1 \pm 0.2$ & $14.7 \pm 1.3$ \\
\hline $\mathrm{RL}$ & $1.4 \pm 0.5$ & $2.6 \pm 0.2$ & $47.4 \pm 2.3$ & $42.8 \pm 2.9$ & $35.5 \pm 2.7$ & $39.6 \pm 2.9$ & $1.9 \pm 0.5$ & $11.9 \pm 1.0$ \\
\hline KK80 & $0.4 \pm 0.1$ & $2.0 \pm 0.2$ & $50.5 \pm 1.8$ & $41.7 \pm 2.2$ & $38.4 \pm 1.9$ & $42.7 \pm 2.6$ & $2.6 \pm 0.6$ & $13.8 \pm 0.5$ \\
\hline SKK & $1.2 \pm 0.3$ & $2.9 \pm 0.3$ & $47.6 \pm 1.7$ & $34.0 \pm 3.0$ & $35.4 \pm 1.6$ & $46.3 \pm 3.2$ & $0.9 \pm 0.2$ & $11.4 \pm 0.6$ \\
\hline MK & $1.0 \pm 0.4$ & $2.9 \pm 0.3$ & $43.1 \pm 1.4$ & $39.4 \pm 2.8$ & $33.0 \pm 2.7$ & $39.9 \pm 1.3$ & $1.3 \pm 0.4$ & $13.0 \pm 1.4$ \\
\hline Mean & $1.0 \pm 0.4$ & $2.4 \pm 0.3$ & $45.9 \pm 3.5$ & $41.5 \pm 4.6$ & $35.3 \pm 3.4$ & $40.5 \pm 4.6$ & $1.4 \pm 0.6$ & $12.3 \pm 1.5$ \\
\hline $\mathrm{MSD}_{0.05}$ & 0.5 & 0.4 & 3.4 & 4.5 & 3.7 & 4.6 & 0.7 & 1.6 \\
\hline
\end{tabular}

Data are expressed as mean \pm standard deviation $(n=10)$; TSS $=$ total soluble solids; MSD $=$ minimum significant difference by Bonferroni test at 0.05 level.

Table 3 ANOVA showing genotype mean square and probabilities of test statistics for the antioxidant properties in 9 selected $S_{3}$ papaya breeding lines.

\begin{tabular}{lrc}
\hline Trait & Genotype mean square & $p$ \\
\hline Ascorbic acid & 2912.19 & $<0.01$ \\
Total phenolic content & 513.21 & $<0.01$ \\
Total flavonoid content & 60.95 & $<0.01$ \\
Antioxidant activity & 10.15 & $<0.01$ \\
Lycopene content & 30.50 & $<0.01$ \\
$\beta$-carotene content & 17.80 & $<0.01$ \\
\hline
\end{tabular}

Hence this study confirms that our selected $S_{3}$ papaya breeding lines are of a high fruit quality for consumer preference.

\section{Antioxidant properties}

The ascorbic acid content, total phenolic content, total flavonoid content, antioxidant activity, lycopene, and $\beta$-carotene in ripe papaya fruits of nine selected $\mathrm{S}_{3}$ papaya breeding lines revealed significant differences $(p<0.01)$ (Table 3$)$. The variation of antioxidants is essential for improving new papaya cultivars with high antioxidants and carotenoids.

The average of the ascorbic acid content was $93 \pm 23 \mathrm{mg} / 100 \mathrm{ml}$. The highest content of ascorbic acid was obtained from KK80 $(114 \pm 20 \quad \mathrm{mg} / 100 \mathrm{ml})$, whereas $\mathrm{RL}$ $(66.1 \pm 9.7 \mathrm{mg} / 100 \mathrm{ml})$ was the lowest (Table 4). This was similar to other reports for papaya that ranged from $59.3-112.4 \mathrm{mg} / 100 \mathrm{~g}^{17,18}$. The ascorbic acid level in papaya fruit was relatively high compared to other tropical fruits. The ranges of ascorbic acid were $82.7 \mathrm{mg} / 100 \mathrm{~g} \mathrm{FW}$ in guava ${ }^{19}$, $55.0 \mathrm{mg} / 100 \mathrm{~g}$ FW in mango, $26.9 \mathrm{mg} / 100 \mathrm{~g}$ FW in pineapple, $7.2 \mathrm{mg} / 100 \mathrm{~g} \mathrm{FW}$ in banana ${ }^{20}$, $67.0 \mathrm{mg} / 100 \mathrm{~g} \mathrm{FW}$ in orange, $8.0 \mathrm{mg} / 100 \mathrm{~g} \mathrm{FW}$ in dragon fruit, $5.8 \mathrm{mg} / 100 \mathrm{~g} \mathrm{FW}$ in mangosteen, $5.2 \mathrm{mg} / 100 \mathrm{~g}$ FW in star fruit, $4.1 \mathrm{mg} / 100 \mathrm{~g} \mathrm{FW}$ in wax apple, and $3.9 \mathrm{mg} / 100 \mathrm{~g} \mathrm{FW}$ in langsat ${ }^{21}$.

Attention has recently increased in phenolic compounds because of their antioxidant and free radical scavenging properties. The average of total phenolic content was $58.0 \pm 8.9 \mathrm{mg}$ GAE/100 g FW. KK80 (72.2 $\pm 5.8 \mathrm{mg} \mathrm{GAE} / 100 \mathrm{~g} \mathrm{FW})$ had the highest content and RL (47.2 $\pm 4.0 \mathrm{mg} \mathrm{GAE} / 100 \mathrm{~g}$ FW) had the lowest value (Table 4). Likewise, Patthamakanokporn et $\mathrm{al}^{22}$ found that the phenolic content of fresh papaya purchased from the markets in Bangkok, Thailand was $54 \mathrm{mg}$ GAE/100 g FW, whereas the Malaysian 'Eksotika' papaya collected from farms was $60.40 \mathrm{mg} / 100 \mathrm{~g}$ $\mathrm{FW}^{23}$. Furthermore, the total phenolic content of juices of 'Sunrise Solo', 'Red Lady', and 'Tainung' cultivars grown under greenhouse conditions in Turkey had values of 65,53 , and $41 \mathrm{mg}$ GAE/100 g FW, respectively ${ }^{24}$. The total phenolics content in papaya displayed a moderate level when compared to other tropical fruits, including guava (168.2 mg GAE/100 $\mathrm{g} \mathrm{FW})^{21}$, sugar apple (129.7 mg GAE/100 g FW), mango (93.6 mg GAE/100 g FW), pineapple (75.0 mg GAE/100 g FW), banana (93.6 mg GAE/100 g FW), wax apple (48.3 mg GAE/100 g FW), jackfruit (26.9 mg $\mathrm{GAE} / 100 \mathrm{~g} \mathrm{FW}$ ), and pomelo (12.4 mg GAE/100 g FW ${ }^{25}$. Nevertheless, it was relatively low compared to berry fruits, such as black mulberry 
Table 4 The content of ascorbic acid, total phenolics, total flavonoids, antioxidant activity, lycopene, and $\beta$-carotene in 9 selected $S_{3}$ papaya breeding lines.

\begin{tabular}{lcccccc}
\hline Genotype & $\begin{array}{c}\text { Ascorbic acid } \\
(\mathrm{mg} /\end{array}$ & $\begin{array}{c}\text { Total phenolics } \\
(\mathrm{mg} \mathrm{GAE} /\end{array}$ & $\begin{array}{c}\text { Total flavonoids } \\
(\mathrm{mg} \mathrm{CE} /\end{array}$ & $\begin{array}{c}\text { Antioxidant } \\
(\mu \mathrm{mol} \mathrm{AAE} / \\
\mathrm{g} \mathrm{FW})\end{array}$ & $\begin{array}{c}\text { Lycopene } \\
(\mathrm{mg} /\end{array}$ & $\begin{array}{c}\beta \text {-carotene } \\
(\mathrm{mg} /\end{array}$ \\
& $100 \mathrm{ml})$ & $100 \mathrm{~g} \mathrm{FW})$ & $100 \mathrm{~g} \mathrm{FW})$ & $\begin{array}{c}\text { FW) } \\
100 \mathrm{~g} \mathrm{FW})\end{array}$ \\
\hline KD2 & $87 \pm 16$ & $54.8 \pm 3.1$ & $13.0 \pm 2.3$ & $5.5 \pm 0.4$ & $10.3 \pm 1.3$ & $8.5 \pm 1.9$ \\
KD5 & $86 \pm 21$ & $56.4 \pm 5.8$ & $14.5 \pm 4.8$ & $5.8 \pm 1.1$ & $9.6 \pm 2.1$ & $7.4 \pm 1.8$ \\
KD7 & $104 \pm 22$ & $57.4 \pm 8.1$ & $21.0 \pm 5.8$ & $6.3 \pm 1.3$ & $11.0 \pm 1.7$ & $10.0 \pm 1.7$ \\
KD22 & $112 \pm 20$ & $59.1 \pm 5.3$ & $17.6 \pm 4.0$ & $6.9 \pm 1.2$ & $9.0 \pm 0.8$ & $8.8 \pm 1.4$ \\
PML & $100.5 \pm 9.4$ & $64.2 \pm 3.5$ & $16.9 \pm 4.0$ & $5.7 \pm 0.5$ & $7.2 \pm 2.1$ & $8.7 \pm 1.5$ \\
RL & $66.1 \pm 9.7$ & $47.2 \pm 4.0$ & $12.8 \pm 5.1$ & $5.0 \pm 0.8$ & $7.5 \pm 1.6$ & $5.6 \pm 1.0$ \\
KK80 & $114 \pm 20$ & $72.2 \pm 5.8$ & $14.8 \pm 3.2$ & $8.0 \pm 1.0$ & $6.2 \pm 0.8$ & $7.0 \pm 1.6$ \\
SKK & $70 \pm 10$ & $50.0 \pm 7.0$ & $16.0 \pm 4.6$ & $4.6 \pm 0.7$ & $6.1 \pm 1.1$ & $6.2 \pm 1.1$ \\
MK & $94 \pm 13$ & $59.0 \pm 6.6$ & $16.3 \pm 1.9$ & $6.6 \pm 0.6$ & $9.6 \pm 1.2$ & $7.5 \pm 0.9$ \\
Mean & $93 \pm 23$ & $58.0 \pm 8.9$ & $15.9 \pm 4.7$ & $6.0 \pm 1.3$ & $8.4 \pm 2.2$ & $7.8 \pm 2.0$ \\
MSD $_{0.05}$ & 26.1 & 9.0 & 6.7 & 1.5 & 2.4 & 2.4 \\
\hline
\end{tabular}

Data were expressed as mean \pm SD $(n=10) ; \mathrm{MSD}=$ minimum significant difference by Bonferroni test at 0.05 level.

(1422 mg/100 g FW) that constitutes an exceptional source of phenolic compounds ${ }^{26}$.

Flavonoid as phenolic compounds are very effective antioxidants. Total flavonoid content ranged from $12.8 \pm 5.1 \mathrm{mg} \mathrm{CE} / 100 \mathrm{~g} \mathrm{FW}$ (RL) to $21.0 \pm 5.8 \mathrm{mg} \mathrm{CE} / 100 \mathrm{~g}$ FW (KD7) with an average of $15.9 \pm 4.7 \mathrm{mg} \mathrm{CE} / 100 \mathrm{~g} \mathrm{FW}$ (Table 4). This was lower than those in the Malaysian 'Eksotika' $(38.12 \mathrm{mg} / 100 \mathrm{~g} \mathrm{FW})^{23}$ and 'Hongkong' papayas $(36.26 \mathrm{mg} / 100 \mathrm{~g} \mathrm{FW})^{27}$. Recently, Spínola et $\mathrm{al}^{28}$ reported that the quantification of total flavonoid content of local and imported papaya in Portugal was 20.5 and $15.3 \mathrm{mg}$ quercetin equivalents $/ 100 \mathrm{~g}$ juice, respectively. It, therefore, indicates that the massive variation of flavonoid content in papaya is due to genetic difference. Moreover, variability of flavonoid content is possibly affected by growing locations, agricultural practices, harvesting, storage conditions, processing, and preparation methods ${ }^{29}$. In this study, samples were prepared in the same condition. Hence further research for this field of study is required. The flavonoid content in papaya fruit was lower than those in apple ${ }^{30}$, guava ${ }^{19}$, star fruit, and jackfruit ${ }^{31}$ with the mean value of 48.5, 41.5, 42.6, and $18.3 \mathrm{mg} \mathrm{CE} / 100 \mathrm{~g} \mathrm{FW}$, respectively. Conversely, it was higher than those in blond to orange-fleshed orange $(12.1 \mathrm{mg} \mathrm{CE} / 100 \mathrm{~g} \mathrm{FW})^{30}$, banana (4.7 mg CE/100 g FW), and pineapple $(1.4 \mathrm{mg} \mathrm{CE} / 100 \mathrm{~g} \mathrm{FW})^{32}$.

The free radical scavenging capacity or antioxidant activity averaged $6.0 \pm 1.3 \mu \mathrm{mol} \mathrm{AAE} / \mathrm{g}$ FW. This was highest in KK80 $(8 \pm 1.0 \mu \mathrm{mol} \mathrm{AAE} / \mathrm{g}$ FW) and lowest in SKK (4.6 $\pm 0.7 \mu \mathrm{mol}$ AAE/g FW)
(Table 4). In a preceding report, papaya antioxidant activity was similar to this study, with $7.4 \mu \mathrm{mol}$ $\mathrm{AAE} / \mathrm{g} \mathrm{FW}$ in the 'Pluk Mailai' cultivar ${ }^{25}$. This result is also in accord with Chinese papaya collected from a supermarket, with an antioxidant capacity of $5.2 \mu \mathrm{mol} \mathrm{Fe}(\mathrm{II}) / \mathrm{g} \mathrm{FW}^{33}$. Compared to other tropical fruits, papaya had a medium level of antioxidant activity, similar to wax apple $(6.2 \mu \mathrm{mol} \mathrm{AAE} / \mathrm{g}$ $\mathrm{FW})$, higher than pineapple $(5.6 \mu \mathrm{mol} \mathrm{AAE} / \mathrm{g} \mathrm{FW})$, jackfruit $(5.5 \mu \mathrm{mol} \mathrm{AAE} / \mathrm{g} \mathrm{FW})$, banana $(5.3 \mu \mathrm{mol}$ $\mathrm{AAE} / \mathrm{g} \mathrm{FW}$ ), watermelon ( $4.6 \mu \mathrm{mol} \mathrm{AAE} / \mathrm{g} \mathrm{FW})$, and coconut $(4.2 \mu \mathrm{mol} \mathrm{AAE} / \mathrm{g}$ FW) but lower than star fruit $(23.3 \mu \mathrm{mol}$ AAE/g FW), tamarind $(19.3 \mu \mathrm{mol}$ $\mathrm{AAE} / \mathrm{g} \mathrm{FW})$, and guava $(17.6 \mu \mathrm{mol} \mathrm{AAE} / \mathrm{g} \mathrm{FW})^{25}$.

Quantification of lycopene content averaged $8.4 \pm 2.2 \mathrm{mg} / 100 \mathrm{~g} \quad \mathrm{FW}$, ranging from $6.1 \pm 1.1 \mathrm{mg} / 100 \mathrm{~g} \mathrm{FW}$ in SKK to $11.0 \pm 1.7 \mathrm{mg} / 100 \mathrm{~g} \mathrm{FW}$ in KD7 (Table 4). A previous report ${ }^{13}$ found the lycopene contents in 'Khaek Dam' and 'Pluk Mailai' papayas for 3.4 and $7.4 \mathrm{mg} / 100 \mathrm{~g} \mathrm{FW}$, respectively. The $2.2 \mathrm{mg} / 100 \mathrm{~g}$ of lycopene content in the "Khaek Dam' papaya was obtained by HPLC ${ }^{34}$. Setiawan et $\mathrm{al}^{35}$ reported $5.8 \mathrm{mg} / 100 \mathrm{~g}$ of lycopene content in papaya from Indonesia. The average $\beta$-carotene content was $7.8 \pm 2.0 \mathrm{mg} / 100 \mathrm{~g} \mathrm{FW}$, ranging from $5.6 \pm 1.0 \mathrm{mg} / 100 \mathrm{~g} F W$ in RL to $10.0 \pm 1.7 \mathrm{mg} / 100 \mathrm{~g}$ FW in KD7 (Table 4). These were higher than those in 'Khaek Dam' (2.7 mg/100 g FW) and 'Pluk Mailai' papayas $(5.8 \mathrm{mg} / 100 \mathrm{~g} \mathrm{FW})$ reported by Chantorn ${ }^{13}$. Our study indicated that our selected KD7 contained $\beta$-carotene approximately 10 times higher than those reported in the commercial 
Table 5 Correlation coefficients between antioxidant compounds, antioxidant activity, and fruit quality traits.

\begin{tabular}{|c|c|c|c|c|c|c|c|c|c|c|c|c|c|}
\hline Trait $^{\dagger}$ & FW & FT & $L$ & $a$ & $b$ & Hue & FF & TSS & AA & $\mathrm{AOA}$ & ТPC & TFC & LC \\
\hline FT & $0.65^{* *}$ & & & & & & & & & & & & \\
\hline$L$ & $-0.51^{* * *}$ & $-0.31^{* * *}$ & & & & & & & & & & & \\
\hline$a$ & $0.01^{\mathrm{ns}}$ & $-0.48^{* * *}$ & $-0.34^{* * *}$ & & & & & & & & & & \\
\hline$b$ & $-0.50^{* * *}$ & $-0.34^{* * *}$ & $0.82^{* * *}$ & $-0.15^{\mathrm{ns}}$ & & & & & & & & & \\
\hline Hue & $-0.30^{* *}$ & $0.14^{\mathrm{ns}}$ & $0.73^{* * *}$ & $-0.80^{* *}$ & $0.71^{* * *}$ & & & & & & & & \\
\hline $\mathrm{FF}$ & $-0.04^{\mathrm{ns}}$ & $-0.15^{\mathrm{ns}}$ & $0.19^{\text {ns }}$ & $0.10^{\mathrm{ns}}$ & $0.08^{\text {ns }}$ & $-0.05^{\mathrm{ns}}$ & & & & & & & \\
\hline TSS & $-0.42^{* *}$ & $-0.13^{\mathrm{ns}}$ & $0.27^{*}$ & $-0.04^{\mathrm{ns}}$ & $0.37^{* *}$ & $0.25^{*}$ & $0.15^{\mathrm{ns}}$ & & & & & & \\
\hline AA & $-0.44^{* * *}$ & $-0.47^{* *}$ & $0.10^{\mathrm{ns}}$ & $0.34^{* * *}$ & $0.25^{*}$ & $-0.09^{\mathrm{ns}}$ & $0.10^{\mathrm{ns}}$ & $0.44^{* * *}$ & & & & & \\
\hline $\mathrm{AOA}$ & $-0.45^{* * *}$ & -0.50 & $0.18^{\text {ns }}$ & $0.35^{* * *}$ & $0.24^{*}$ & $-0.10^{\mathrm{ns}}$ & $0.32^{* *}$ & 0.25 & $0.60^{* * *}$ & & & & \\
\hline TPC & $-0.64^{* * *}$ & $-0.50^{* * *}$ & $0.25^{*}$ & $0.20^{\mathrm{ns}}$ & $0.36^{* * *}$ & $0.07^{\mathrm{ns}}$ & $0.22^{\text {ns }}$ & $0.56^{* * *}$ & $0.60^{* * *}$ & $0.77^{* *}$ & & & \\
\hline $\mathrm{TFC}$ & $-0.26^{*}$ & $-0.26^{*}$ & $0.14^{\mathrm{ns}}$ & $0.00^{\mathrm{ns}}$ & $0.17^{\mathrm{ns}}$ & $0.11^{\mathrm{ns}}$ & $-0.16^{\mathrm{ns}}$ & $0.00^{\mathrm{ns}}$ & $0.11^{\mathrm{ns}}$ & $0.23^{*}$ & $0.07^{\mathrm{ns}}$ & & \\
\hline LC & $0.14^{\mathrm{ns}}$ & $-0.10^{\mathrm{ns}}$ & $-0.62^{* * *}$ & $0.54^{* *}$ & $-0.47^{* *}$ & $-0.67^{* *}$ & $-0.25^{*}$ & $-0.12^{\mathrm{ns}}$ & $0.16^{\mathrm{ns}}$ & $0.12^{\mathrm{ns}}$ & $-0.04^{\mathrm{ns}}$ & $0.18^{\mathrm{ns}}$ & \\
\hline BC & $-0.24^{*}$ & $-0.33^{* * *}$ & $-0.16^{\mathrm{ns}}$ & $0.33^{* * *}$ & $0.05^{\mathrm{ns}}$ & $-0.20^{\mathrm{ns}}$ & $-0.19^{\mathrm{ns}}$ & $0.17^{\mathrm{ns}}$ & $0.43^{* * *}$ & $0.38^{\mathrm{ns}}$ & $0.37^{* *}$ & $0.39^{* * *}$ & $0.62^{* * *}$ \\
\hline
\end{tabular}

${ }^{\dagger} \mathrm{FW}=$ fruit weight; $\mathrm{FT}=$ flesh thickness; Hue = hue angle; $\mathrm{FF}=$ flesh firmness; $\mathrm{AA}=$ ascorbic acid; $\mathrm{AOA}=$ antioxidant activity; TPC $=$ total phenolic content; $\mathrm{TFC}=$ total flavonoid content; $\mathrm{LC}=$ lycopene; $\mathrm{BC}=\beta$-carotene. ${ }^{\mathrm{ns}}$ non-significant; * and ${ }^{* *}$ represent significance at $p<0.05$ and 0.01 , respectively.

'Khaek Dam'. Interestingly, the lycopene in the papaya flesh of this report was substantially higher than in other reports. Consequently, this study confirms that our selected $S_{3}$ papaya breeding lines are excellent sources of carotenoids. Moreover, red-fleshed papaya (KD Group and MK) have more lycopene and $\beta$-carotene content than orange-fleshed papayas (RL, KK80, and SKK).

Noticeably, among 9 selected $S_{3}$ papaya breeding lines, KK80 line had the highest of antioxidant activity, ascorbic acid and total phenolic content but not of total flavonoid, lycopene, or $\beta$-carotene content (Table 4). Coincidently with fairly high of $b$ and hue values in KK80 line (Table 2), the expansion of $b$ and hue values reflects reduction of lycopene and $\beta$-carotene contents. Generally, accumulation of carotenoid pigments in flesh fruits influence to visual colour intensity. For example, tomato and watermelon with vivid red, orange and yellow flesh as papaya were reported that red flesh accumulates higher lycopene. Red to orange flesh has a major constituent of lycopene and $\beta$-carotene. In contrast, yellow flesh is abundant of $\beta$-cryptoxanthin (papaya), violaxanthin (watermelon) with almost lack of lycopene ${ }^{34,36}$. Among KD group, based on main commercial cultivar in Thailand for years as 'Khaek Dam', we found the variation of antioxidant properties among same cultivar, especially ascorbic acid, total flavonoid, and $\beta$-carotene content. Accordingly, Iamjud et $\mathrm{al}^{37}$ demonstrated a difference of growth and fruit quality of 7 'Khaek Dam' papayas. This study presented that various cultivars show clearly distinct amount of antioxidant properties. Similar as several works were previously reported $^{19,24}$.

\section{Correlations}

Knowledge of the association between fruit quality traits and antioxidants will assist plant breeders in choosing which traits should be used for breeding programs and indirect selection. Largely correlated traits may indicate an opportunity to improve overall efficiency by reducing the number of traits required to determine the best cultivar to fulfil their requirement. Moreover, the knowledge of these associations will advise the breeder which traits should be viewed with caution in a breeding program.

Pearson's correlations (Table 5) show the high positive correlation coefficient $(r=0.65)$ existing in fruit weight with flesh thickness. According to Oliveira et $\mathrm{al}^{38}$, it is possible to simultaneously improve fruit size and flesh thickness. Fruit size had a negative correlation with antioxidants and total soluble solids. For example, fruit weight moderately strong negatively correlated with total phenolic content $(-0.64)$; moderately weak correlated with antioxidant activity $(-0.45)$, ascorbic acid $(-0.44)$, and TSS $(-0.42)$; and very weak correlated with total flavonoid content $(-0.26)$. These results indicated that selection for large fruit size may have a reducing effect on antioxidants and TSS in papaya fruit, similar to previous findings in guava fruit ${ }^{39}$. Flesh thickness also had a moderately strong negative correlation with antioxidants, indicating that developing new varieties with high flesh thickness 
may have an adverse effect on antioxidant content.

Lycopene represents the red colour and $\beta$-carotene represents the yellow and orange colour in many vegetables and fruits. A highly negative correlation was found between lycopene content and hue value $(-0.67)$, moderately high with $L$ $(-0.62)$, and moderately weak with $b(-0.47)$, while a moderately high positive correlation with $a$ (0.54). The increase in the intensity of the orange-red colour of the flesh was accompanied by a decrease in the values of hue, $L$, and $b$, and an increase in the values of $a$. $\beta$-Carotene had no correlation with $L, b$, and hue value. In contrast, $\beta$-carotene had a negative correlation with $a$ value $(-0.33)$, but weakly was correlated and close to the zero. Lycopene showed the best correlation with hue value. The hue angle maybe therefore of use for indirectly determining lycopene content. Moreover, lycopene had a moderately high positive correlation with $\beta$-carotene (0.62), indicating an increase in both lycopene and $\beta$-carotene.

Ascorbic acid's relatively high positive values correlated with both antioxidant activity $(0.60)$ and total phenolic content $(0.60)$ in papaya fruit. Antioxidant activity showed a high positive correlation with total phenolic content (0.77). Another investigator has reported similar result ${ }^{40}$. Antioxidant activity revealed a higher positive correlation with total phenolic compounds than with ascorbic acid, and total flavonoid compounds indicated that total phenolics were a more important contributor to antioxidant activity in papaya fruit than ascorbic acid or flavonoids. This suggested that the total phenolic and/or ascorbic acid content could be used in screening indirectly for antioxidant activity in papaya since the evaluation methods are simple and do not involve the use of hazardous chemicals.

\section{CONCLUSIONS}

Our results show a significant variation in antioxidant properties and fruit qualities in nine selected $\mathrm{S}_{3}$ papaya breeding lines and this investigation clearly shows the potential value of selected papaya genotypes as new cultivars and their possible use in breeding programs for improving new papaya cultivars with high antioxidant properties. Redderfleshed genotypes (KD and MK) had lycopene and $\beta$-carotene greater than other orange-fleshed genotypes (RL, KK80, or SKK). Fruit size had a negative correlation with antioxidants, indicating that selection for large fruit size may have a reducing effect on antioxidants. Flesh colour as hue angle had a highly negative correlation with lycopene content.
This indicated that the hue angle maybe of use for indirect determination of lycopene content.

Acknowledgements: This study was financially supported by the Thailand Research Fund and a scholarship for international publication of the Graduate School, Kasetsart University, Thailand.

\section{REFERENCES}

1. Rice-Evans CA, Miller NJ, Paganga G (1997) Antioxidant properties of phenolic components. Trends Plant Sci 2, 152-9.

2. Aravind G, Bhowmik D, Duraivel S, Harish G (2013) Traditional and medicinal uses of Carica papaya. $J$ Med Plants Stud 1, 7-15.

3. Srimat $\mathrm{S}$, Suwanphong $\mathrm{N}$, Boonprakob U, Thaipong K (2014) Correlations between fruit size and antioxidant contents in guava. Acta Hort 1024, 407-12.

4. Ornelas-Paz JdJ, Yahia EM, Gardea AA (2008) Changes in external and internal color during postharvest ripening of 'Manila' and 'Ataulfo' mango fruit and relationship with carotenoid content determined by liquid chromatography-APcI ${ }^{+}$-time-offlight mass spectrometry. Postharvest Biol Tech 50, $145-52$.

5. Arias R, Lee TC, Logendra L, Janes H (2000) Correlation of lycopene measured by HPLC with the $L^{*}$, $a^{*}, b^{*}$ color readings of a hydroponic tomato and the relationship of maturity with color and lycopene content. J Agr Food Chem 48, 1697-702.

6. Santamaría Basulto F, Sauri Duch E, Espadas y Gil F, Díaz Plaza R, Larqué Saavedra A, Santamaría JM (2009) Postharvest ripening and maturity indices for Maradol papaya. Interciencia $34,583-8$.

7. McGuire RG (1992) Reporting of objective color measurements. Hortscience 27, 1254-5.

8. Association of Official Analytical Chemists (1990) Official Method of Analysis, AOAC, Virginia.

9. Swain T, Hillis WE (1959) The phenolic constituents of Prunus domestica. I.-The quantitative analysis of phenolic constituents. J Sci Food Agr 10, 63-8.

10. Zhishen J, Mengcheng T, Jianming W (1999) The determination of flavonoid contents in mulberry and their scavenging effects on superoxide radicals. Food Chem 64, 555-9.

11. Benzie IFF, Strain JJ (1996) The ferric reducing ability of plasma (FRAP) as a measure of "antioxidant power": the FRAP assay. Anal Biochem 239, 70-6.

12. Anthon G, Barrett DM (2007) Standardization of a rapid spectrophotometric method for lycopene analysis. Acta Hort 758, 111-27.

13. Chantorn T (2013) Correlation between flesh color and carotenoid contents in papaya fruit. BSc special problem, Kasetsart Univ, [in Thai with English abstract].

14. Nishijima KA, Wall MM, Fitch MM (2010) Evaluating Hawaii-grown papaya for resistance to internal 
yellowing disease caused by Enterobacter cloacae. Hortscience 45, 1357-64.

15. Sangwanangkul P, Chanseetis J, Thongbor S, Muttavarat P (2009) A Study on Variety, Processing and Marketing of Papaya Case Study: Kanchanaburi Province and Supanburi Province, Research and Development Institute at Kamphaengsaen, Kasetsart Univ, Nakhon Pathom, [in Thai with English abstract].

16. Hawaii Department of Agriculture (1990) Standards for Hawaii-Grown Papaya, Marketing Division, HDOA, Hawaii.

17. Sangwanangkul P, Iamjud K, Rittiron R, Thaipong K (2011) Nondestructive evaluation of vitamin C in 'Plugmailai' papaya fruit by NIRs technique. Agr Sci $J$ 42,(Suppl.), 75-8, [in Thai with English abstract].

18. Souza LM, Ferreira KS, Chaves JBP, Teixeira SL (2008) L-ascorbic acid, $\beta$-carotene and lycopene content in papaya fruits (Carica papaya) with or without physiological skin freckles. Sci Agr 65, 246-50.

19. Sanguansil S, Boonprakob U, Thaipong K (2014) Quantification of antioxidant content in fruit of guava germplasm. Acta Hort 1024, 385-90.

20. Hernández Y, Lobo MG, González M (2006) Determination of vitamin $\mathrm{C}$ in tropical fruits: A comparative evaluation of methods. Food Chem 96, 654-64.

21. Lim YY, Lim TT, Tee JJ (2007) Antioxidant properties of several tropical fruits: A comparative study. Food Chem 103, 1003-8.

22. Patthamakanokporn O, Puwastien P, Nitithamyong A, Sirichakwal PP (2008) Changes of antioxidant activity and total phenolic compounds during storage of selected fruits. J Food Compos Anal 21, 241-8.

23. Addai ZR, Abdullah A, Mutalib SA, Musa KH, Douqan EMA (2013) Antioxidant activity and physicochemical properties of mature papaya fruit (Carica papaya L. cv. Eksotika). Adv J Food Sci Tech 5, 859-65.

24. Özkan A, Gübbük H, Güneş E, Erdoğan A (2011) Antioxidant capacity of juice from different papaya (Carica papaya L.) cultivars grown under greenhouse conditions in Turkey. Turk J Biol 35, 619-25.

25. Thaipong K, Thanutong P (2011) Antioxidant content of Thai fruits. In: The International Symposium on Tropical and Subtropical Fruits, 29 Nov-2 Dec 2011, Chiang Mai, Thailand, p 126.

26. Ercisli S, Orhan E (2007) Chemical composition of white (Morus alba), red (Morus rubra) and black (Morus nigra) mulberry fruits. Food Chem 103, 1380-4.

27. Zuhair RA, Aminah A, Sahilah AM, Eqbal D (2013) Antioxidant activity and physicochemical properties changes of papaya (Carica papaya L. cv. Hongkong) during different ripening stage. Int Food Res $J$ 20, 1653-9.

28. Spínola V, Pinto J, Castilho PC (2014) Identification and quantification of phenolic compounds of selected fruits from Madeira Island by HPLC-DAD-ESI-MS ${ }^{n}$ and screening for their antioxidant activity. Food Chem 173, 14-30.

29. Haytowitz DB, Bhagwat S, Holden JM (2013) Sources of variability in the flavonoid content of foods. Procedia Food Sci 2, 46-51.

30. Srivastava MP, Tiwari R, Sharma N (2013) Assessment of phenol and flavonoid content in the plant materials. J New Biol Rep 2, 163-6.

31. Barreto GPM, Benassi MT, Mercadante AZ (2009) Bioactive compounds from several tropical fruits and correlation by multivariate analysis to free radical scavenger activity. J Braz Chem Soc 20, 1856-61.

32. Alothman M, Bhat R, Karim AA (2009) Antioxidant capacity and phenolic content of selected tropical fruits from Malaysia, extracted with different solvents. Food Chem 115, 785-8.

33. Fu L, Xu BT, Xu XR, Gan RY, Zhang Y, Xia EQ, Li HB (2011) Antioxidant capacities and total phenolic contents of 62 fruits. Food Chem 129, 345-50.

34. Charoensiri R, Kongkachuichai R, Suknicom S, Sungpuag P (2009) Beta-carotene, lycopene, and alphatocopherol contents of selected Thai fruits. Food Chem 113, 202-7.

35. Setiawan B, Sulaeman A, Giraud DW, Driskell JA (2001) Carotenoid content of selected Indonesian fruits. $J$ Food Compos Anal 14, 169-76.

36. Yuan H, Zhang J, Nageswaran D, Li L (2015) Carotenoid metabolism and regulation in horticultural crops. Hort Res 2, 15036.

37. Iamjud K, Srimat S, Wasee S, Sangwanangkul P, Thaipong K (2013) Growth and fruit quality of 7 'Khaek Dam' papaya varieties. Agr Sci J 44,(Suppl), 257-60, [in Thai with English abstract].

38. Oliveira EJ, Fraife Filho GA, Freitas JPX, Dantas JLL, Resende MDV (2012) Plant selection in $\mathrm{F}_{2}$ segregating populations of papaya from commercial hybrids. Crop Breed Appl Biotechnol 12, 191-8.

39. Sanguansil S (2012) Genotype by environment interaction of phenolic compounds in guava fruit. MSc thesis, Kasetsart Univ, [in Thai with English abstract].

40. Corral-Aguayo RD, Yahia EM, Carrillo-Lopez A, González-Aguilar G (2008) Correlation between some nutritional components and the total antioxidant capacity measured with six different assays in eight horticultural crops. J Agr Food Chem 56, 10498-504. 